\title{
Variability of the Anthracnose Fungus Colletotrichum graminicola in Sorghum Genotype Mixtures
}

\author{
Henrique M. Valério ${ }^{1}$, Carlos R. Casela ${ }^{2}$, Maria A. Resende ${ }^{1} \&$ Fredolino G. Santos $^{2}$ \\ ${ }^{1}$ Instituto de Ciências Biológicas, UFMG, CEP 31270-901, Belo Horizonte, MG; ${ }^{2}$ Embrapa Milho e Sorgo, Cx.Postal 151, \\ CEP 35701-970, Sete Lagoas, MG, fax (31) 3779-1088, e-mail: casela@cnpms.embrapa.br
}

(Accepted for publication on 01/06/2004)

Corresponding author: Carlos R. Casela

VALÉRIO, H.M., CASELA, C.R., RESENDE, M.A. \& SANTOS, F.G. Variability of the anthracnose fungus Colletotrichum graminicola in sorghum genotype mixtures. Fitopatologia Brasileira 29:567-569. 2004

\begin{abstract}
This paper reports partial results obtained on the variability of Colletotrichum graminicola developed in response to the host diversity generated by three-line combination of sorghum (Sorghum bicolor) genotypes. Nine sorghum lines were used in this study: CMSXS210B, CMSXS112B, CMSXS215B, CMSXS221B, CMSXS169R, CMSXS180R, CMSXS182R, CMSXS227R, and CMSXS116R. A total of 39 treatments on mixtures and pure stands of the component

lines were evaluated in the field for the development of anthracnose, as a natural epidemic. Samples of the single spore isolates of the pathogen of each treatment indicated a reduction in the phenotypic diversity and an increase in the frequency of more complex races in genotype mixtures in relation to the pure stands of each genotype. diversity.

Additional keywords: Sorghum bicolor, diseases, virulence,

\section{RESUMO}

Variabilidade de Colletotrichum graminicola, agente causal da antracnose, em misturas de genótipos de sorgo

O presente trabalho relata resultados parciais sobre a variabilidade de Colletotrichum graminicola, agente causal da antracnose do sorgo (Sorghum bicolor), desenvolvida em resposta à diversidade gerada na população hospedeira através de misturas formadas pela combinação, três a três, de diferentes linhagens de sorgo. Nove linhagens foram utilizadas neste estudo: CMSXS210B, CMSXS112B, CMSXS215B, CMSXS221B, CMSXS169R,

CMSXS180R, CMSXS182R, CMSXS227R, and CMSXS116R. Misturas e estandes puros de cada linhagem componente, em um total de 39 tratamentos, foram avaliados no campo, para o desenvolvimento da antracnose em condições de infecção natural. Amostras de isolados monospóricos do patógeno obtidas de cada tratamento indicaram uma redução na diversidade fenotípica do patógeno e um aumento na freqüência de raças de maior complexidade em todas as misturas em relação aos estandes puros de cada genótipo.
\end{abstract}

Sorghum [Sorghum bicolor (L.) Moench] anthracnose, caused by Colletotrichum graminicola (Ces.) Wils. (Syn. C. sublineolum P. Henn) is the most important disease affecting this crop in Brazil. The disease can reduce the yield of sorghum substantially and is particularly damaging when susceptible cultivars are grown in areas where warm temperatures and high relative humidity predominate throughout the season. Genetic resistance has been the most effective strategy to control the disease, but this resistance has been, at times, transitory because of the high variability present in populations of this pathogen (Ali \& Warren, 1992; Casela et al., 2000). This fact has prompted the search for alternatives that result in a more stable and durable form of resistance. A possible alternative for highly variable pathogens has been the diversification of the host population, through the use of cultivar mixtures or multilines (Browning \& Frey, 1969; Lannou \& Mundt, 1996). This strategy has already been tested in sorghum for the control of anthracnose and leaf blight (Sifuentes \& Frederiksen, 1994; Guimarães et al., 1998). This paper reports partial results obtained on the variability of $C$. graminicola developed in response to the host diversity generated by different threeline combination of sorghum genotypes.
Nine sorghum lines were used in this study: CMSXS210B, CMSXS112B, CMSXS215B, CMSXS221B, CMSXS169R, CMSXS180R, CMSXS182R, CMSXS227R, and CMSXS116R. Mixtures and pure stands of each component line for a total of 39 treatments were evaluated in the field for development of anthracnose in naturally occurring epidemics, in a randomized complete block design with three replications. Mixtures and pure stands were planted in two row plots, separated by two rows of the resistant genotype SC283 to reduce interplot contamination. Rows in each plot were $6.0 \mathrm{~m}$ long, $0.9 \mathrm{~m}$ apart with $0.2 \mathrm{~m}$ between plants. Spreader rows were formed by the susceptible genotype BR009 (Tx623), planted $0.5 \mathrm{~m}$ apart and in front of each block.

The pathotype diversity and complexity of the populations of C. graminicola were evaluated in each treatment. Samples were collected at random from infected plants in each treatment; infected tissues were placed in paper envelopes and kept at room temperatures until isolation. For the production of single spore isolates, host tissue of each specimen was surface sterilized for 1 min with a $0.5 \%$ sodium hypochlorite solution, plated out on oat meal agar (OMA) and incubated under continuous fluorescent light at $25^{\circ} \mathrm{C}$ for seven- 
H.M. Valério et al.

eitght days to induce sporulation. Conidia were harvested by flooding plates with sterile distilled water, followed by serial dilution to obtain a conidial suspension at a concentration of 50-100 spores/ml. One $\mathrm{ml}$ of this suspension was transferred to a Petri dish containing 2\% water-agar and incubated at room temperature under continuous fluorescent light for $12 \mathrm{~h}$ for conidial germination. Individual germinated spores were outlined on the medium by a wire loop fastened below the low power objective of a microscope. The outlined spore was examined for the presence of other spores and if none were observed, the selected spore was transferred to OMA culture tubes. After development, cultures were flooded with sterile mineral oil for maintenance. One conidium per leaf per plant was obtained in each treatment.

The nine sorghum lines and components of the mixtures were used as differentials for the evaluation of the variability of the pathogen in each host population. Lines were planted, in the greenhouse, in a split-plot arrangement using a randomized complete block design, with isolates randomized as whole plots and sorghum genotypes as sub-plots. Due to limitation of space in the greenhouse, isolates were inoculated in groups of five. One experiment consisted of the nine differentials and five isolates in two replications. Each pot containing five-six plants was considered as a replication.

For the evaluation, plants were classified for infection type, 12 days after inoculation, based on a 1 to 5 scale where: 1 = presence of chlorotic flecks; 2 = red spots on the leaf lamina with no sporulation; 3 = necrotic lesions, sometimes elongated, but no acervuli formed; 4 = necrotic lesions formed with acervuli present in the center; and $5=$ necrotic lesions, sometimes coalescing, with abundant formation of acervuli. Disease reactions were separated into two groups: $\mathrm{R}=$ resistant reaction (including infection types 1,2 , and 3 ) and $S=$ susceptible reaction (including infection types 4 and 5). Isolates were separated in groups, according to the number of differential lines to which they were able to produce a susceptible reaction

In all genotype mixtures a reduction in phenotypic diversity and an increase in frequency of more complex races was observed in relation to the pure stands of each genotype, especially in treatments involving lines CMSXS210A, CMSXS112A, CMSXS221A, and CMSXS180R (Figure 1). Despite the development of complex races disease severity was significantly reduced in all susceptible genotypes present in mixtures as compared with disease severity in a pure stand. For example, a reduction in the level of disease severity, variable from 56 to $70 \%$, was observed in the susceptible line CMSXS112A when in mixtures with resistant lines (data not shown). The transitional effectiveness of resistance to variable pathogens such as C. graminicola has demanded considerable efforts in search of a more durable resistance. Efforts have been devoted to the identification and selection of dilatory resistance (Cardwell et al., 1988; Guimarães et al., 1999) and the diversification of the host population, as a way to stabilize the pathogen population and to slow down the rate of disease development (Guimarães et al., 1998). Despite the fact that the
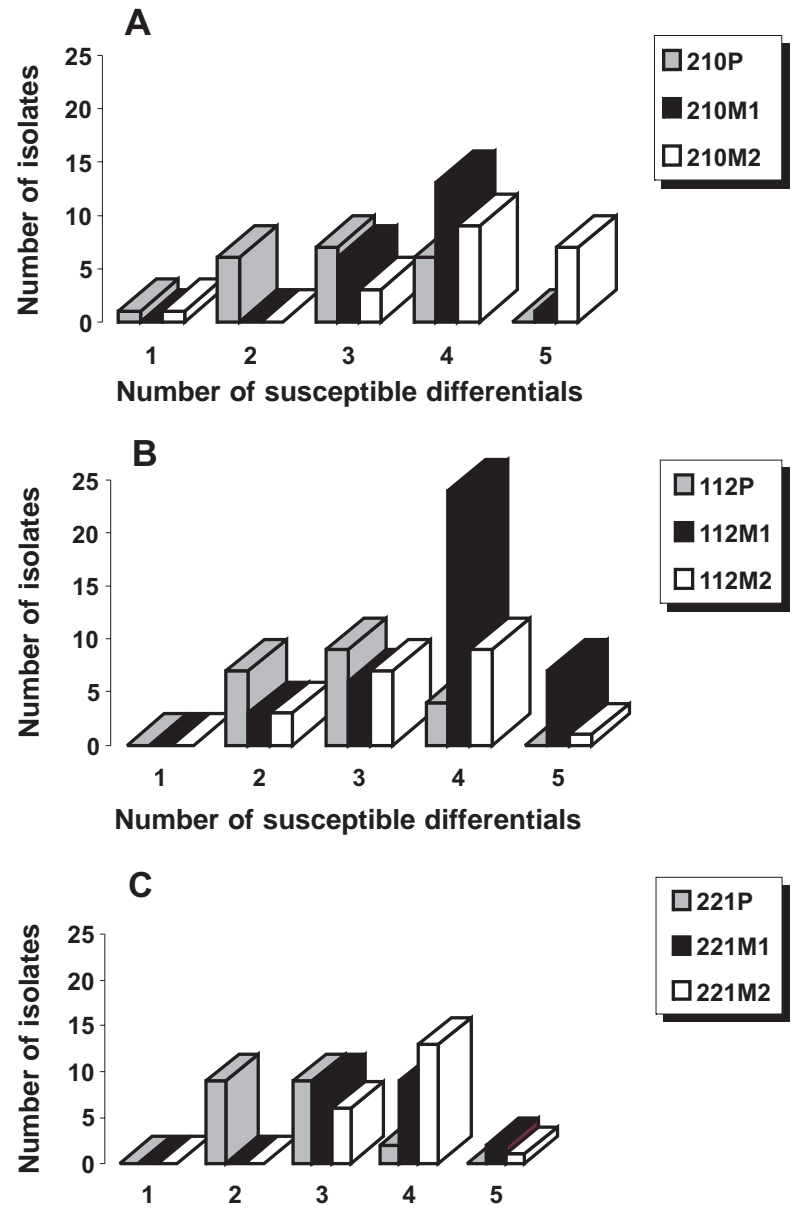

Number of susceptible differentials
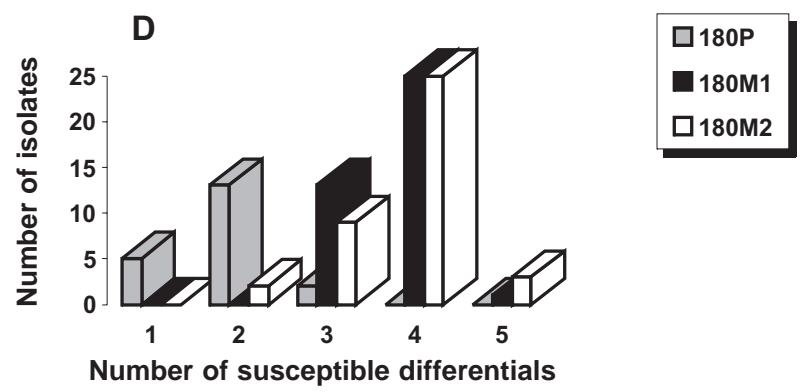

FIG. 1 - Complexity and diversity of Colletotrichum graminicola on four sorghum (Sorghum bicolor) genotypes in pure stand and in three-genotype mixtures. A-Sorghum line CMSXS210 (210P-pure stand, 210M1 - mixture with CMSXS112 and CMSXS180, 210M2mixture with CMSXS112 and CMSXS116); B-Sorghum line CMSXS112 (112P-pure stand, 112M1-mixture with CMSXS210 and CMSXS180, 112M2-mixture with CMSXS210 and CMSXSS116); C-Sorghum line CMSXS221 (221P - pure stand, 221M1-mixture with CMSXS112 and CMSXS180, 221M2-mixture with CMSXS112 and CMSXS116); D-Sorghum line CMSXS180 (180P-pure stand, 180M1-mixture with CMSXS210 and CMSXS112, 180M2-mixture with CMSXS112 and CMSXS221).

effectiveness of host mixtures for controlling epidemics is well documented in the literature (Leonard, 1969; Browning \& Frey, 
Variability of the anthracnose fungus Colletotrichum graminicola in sorghum...

1969), there exists little work reported in the literature relating to the question of the evolution of pathogen populations in response to host mixture.

Different models have been proposed to describe the conditions in which complex races, able to develop on several components of the mixture, are selected and erode the resistance of the mixture. The development of more complex races in genotype mixtures observed in this study agrees with those predicted by Lannou \& Mundt (1996) in their models on pathogen evolution in host mixtures. The development of complex races of $C$. graminicola in mixtures did not affect, however, the effectiveness of the mixture to reduce disease severity in the different treatments evaluated. This efficiency could have been determined by a reduction in fitness of the complex races developed in the genotype mixtures as differences in competitive ability among races with different degrees of complexity have been demonstrated in this pathogen (Casela et al., 2001). A more complete view of the complex racesimple race competition and the efficacy of this strategy in controlling sorghum anthracnose will be possible in the near future with additional data collected from the same mixtures planted in larger plots with a larger number of samples.

\section{LITERATURE CITED}

ALI, M.E.K. \& WARREN, H.L. Anthracnose of sorghum. Proceedings, Sorghum and Millet Diseases: a Second World Review. De Milliano, W.A.J., Frederiksen, R.A. \& Bengston, G.D. (Eds.) Patancheru, A. P. 502324, India. International Crop Research Institute for the Semi-Arid Tropics. 1992. pp.203-208.

BROWNING, J.A. \& FREY, K.J. Multiline cultivars as a mean of disease control. Annual Review of Phytopathology 7:355-382. 1969.

CARDWELL, K.F., COLLINS, S.D. \& FREDERIKSEN, R.A. Dilatory resistance character of sorghum hybrids as measured by area under disease progress curve. Biological and Cultural Tests 3:36. 1988.

CASELA, C.R., SANTOS, F.G. \& FERREIRA, A.S. Associação de patogenicidade e diversidade fenotípica de Colletotrichum graminicola agente causal da antracnose em sorgo. Fitopatologia Brasileira 25:517521. 2000.

CASELA, C.R., FERREIRA, A.S. \& SANTOS, F.G. Differences in competitive ability among races of Colletotrichum graminicola in mixtures. Fitopatologia Brasileira 26:217-219. 2001.

GUIMARÃES, F.B., CASELA, C.R., SANTOS, F.G. DOS \& FERREIRA, A.S. Controle da antracnose do sorgo através da utilização de misturas de cultivares. Summa Phytopathologica 24:131-135. 1998.

GUIMARÃES, F.B., CASELA, C.R., SANTOS, F.G., PEREIRA, J.C.R. \& FERREIRA, A.S. Avaliação da resistência de genótipos de sorgo a antracnose. Summa Phytopathologica 25:308-312. 1999.

LANNOU, C. \& MUNDT, C.C. Evolution of a pathogen population in host mixtures: simple race-complex race competition. Plant Pathology 45:440-453. 1996.

LEONARD, K.J. Selection in heterogeneous populations of Puccinia graminis f. sp. avenae. Phytopathology 59:1851-1857. 1969.

SIFUENTES, J.A.B. \& FREDERIKSEN, R.A. Evaluation of sorghum hybrid mixtures for controlling sorghum leaf blight. Plant disease 78:499-503. 1994. 